\author{
서울시 공공자전거 공유시스템 $(\mathrm{PBSS})$ 의 \\ 시공간적 이용 패턴 분석 \\ - 서울시 여의도동을 중심으로 - \\ 윤승용 ${ }^{*}$ 민경훈 ${ }^{* *} \cdot$ 고하정 ${ }^{* * *}$ \\ "서울대학교 협동과정 조경학 박사과정 - "일본 국립치바대학교 녹지환경과학코스 박사 ·"

\section{Spatio-Temporal Patterns of a Public Bike Sharing System in Seoul - Focusing on Yeouido District -} \\ Yun, Seung-yong ${ }^{*} \cdot$ Min, Kyung-hun ${ }^{* *} \cdot$ Ko, Ha-jung ${ }^{* *}$ \\ ${ }^{*} \mathrm{Ph} . \mathrm{D}$. Candidate, Interdisciplinary Program in Landscape Architecture, \\ Graduate School of Environmental Studies, Seoul National University \\ "Ph.D., Environmental Science and Landscape Architecture Course, Chiba University, Japan \\ ${ }^{* * *}$ Ph.D. Research Fellow, Korea Safety Health Environment Foundation
}

\begin{abstract}
Various policies and studies regarding use of PBSS (Public Bike Sharing System) and Programs (PBSP) have been conducted worldwide as the number systems or programs has increased. Although various phenomena and demands have been generated by the use of PBSS in everyday life, the majority of research and the policies in South Korea have been implemented focused on commuting life. The purpose of this study aimed to understand various PBSS demands using PBSS usage data in 2018 in the Yeouido districts through classifying usage patterns and analyzing features. The rental stations were classified into three types based on weekday/weekend usage rates. The usage of Yeouido's PBSS accounted for $4.3 \%$ of the total usage in Seoul Metropolitan City, while the number of PBSS rental stations accounted for $2 \%$ of all rental stations in the Seoul urban areas. Rental stations with a higher weekday utilization rates showed high utilization rates in all four seasons and were mainly distributed in work and residential areas. Other stations showed a concentrated usage pattern in spring (April-May) and autumn (September-October) seasons, and their locations were close to the entrance of nearby parks. Besides, renting and returning were often concentrated at certain rental stations for high weekend utilization as compared to the pattern of high weekday usage. Therefore, PBSS management and programs should be operated to reflect various usage demands rather than uniform PBSS operations. The result of this study is meaningful to provide basic data for effective PBSS operation by monitoring the demand for PBSS usage in spatio-temporal terms.
\end{abstract}

Key Words: Public Bicycle Sharing System(PBSS), Spatio-Temporal Analysis, Urban Park, Big Data, Yeouido

Corresponding author: Ha-Jung Ko, Ph.D. Research Fellow, Korea Safety Health Environment Foundation, Seoul 06737, Korea, Tel.: +82-2-6215-3883, E-mail: tweety1229@snu.ac.kr 


\section{국문초록}

세계적으로 공공자전거 공유시스템(PBSS) 및 프로그램(PBSP)이 증가하면서 다양한 정책과 연구들이 진행되었다. 오늘날 PBSS가 일상생활에서 밀접하게 이용되면서 다양한 현상과 수요가 발생하고 있으나, 아직 국내에서는 통근통학에 초점을 맞춘 정책과 연구들이 주로 이루어지고 있다. 이에 본 연구는 다양한 PBSS 수요를 파악하기 위해서 서울시 여의도 를 대상으로 2018년도 한 해 동안 발생한 PBSS 이용 데이터를 분석하여 이용 패턴을 유형화하고 특징을 분석하였다. 서울시에서 제공하는 PBSS 자료를 기반으로 주중/주말 이용률에 따라 대여소를 3 개 유형으로 구분하여 각각의 특징을 분석하였다. 여의도의 PBSS는 이용량의 경우에는 서울시 전체에서 $4.3 \%$, 대여소 개소수의 경우에는 $2 \%$ 에 해당하는 것으로 나타났다. 주중 이용률이 높은 대여소는 다른 유형에 비하여 사계절 모두 높은 이용률을 보였으며, 업무 및 주거 지역에 주로 분포하였다. 주말 이용률이 높은 대여소의 경우에는 봄(4 5월)과 가을(9 10월)에 집중된 이용 패턴이 나타났 으며, 대여소에서 공원입구까지의 거리가 가까운 것으로 나타났다. 또한, 주중 이용률이 높은 패턴에 비해서 동일한 대여소를 통해 대여 및 반납이 이루어진 경우가 많고, 특정 대여소에 PBSS 이용이 집중된 쏠림현상이 나타나고 있는 것을 확인할 수 있었다. 따라서, 획일적인 PBSS 운영보다는 대여소별로 다양한 이용수요와 현상을 반영한 PBSS의 관리와 프로그램이 운영되어야 할 것이다. 본 연구결과는 PBSS 이용에 대한 수요를 유형에 따라 시공간적으로 파악함으로써 효과적인 PBSS 운영이 이루어질 수 있도록 기초자료를 제공하는 것에 의의가 있다.

주제어: 공공자전거, 도시공원, 여의도, 빅데이터, 시공간분석

\section{I. 서론}

세계적으로 공공에서 운영하는 공공자전거 공유시스템 (PBSS: Public Bike Sharing System) 또는 공공자전거 공유 프로그램(PBSP: Public Bike Sharing Program)의 수가 급속 히 증가하고 있다. PBSS는 기존연료를 사용하는 이동수단의 대안으로 공공에서 환경적, 경제적, 보건적 효과를 위해 운영되 고 있다. 최근 국내에서도 비동력, 무탄소 교통수단 활성화 정 책을 발표하여 대중교통체계와 연결된 보행·자전거 이용환경 향상을 위한 정책기반이 마련되었다(KOTI, 2018). 이러한 PBSS 의 성장으로 2016년에는 전 세계 1,188 개 PBSS와 230만대의 자전거가 운영되고 있으며, 공유자전거의 성능 및 이용 패턴에 관한 연구가 빠르게 발전해왔다(Metro bike, 2019).

$\mathrm{PBSS}$ 가 발전함에 따라 이용자들의 정보가 전산화되면서 공 유자전거 정류장을 이용한 자전거 수의 변화를 추적할 수 있게 되었다. 수집된 데이터는 PBSS 이용의 시공간적 변화에 대한 정보를 제공하는 것에 도움을 주고 있다(Kaltenbrunner et al., 2010). 기상 및 시계열 조건은 PBSS의 이용에 가장 많은 영향 을 미치는 것으로 알려졌다. 눈과 비가 오거나 기온이 높거나 낮은 경우(혹서기, 혹한기) 자전거 이용이 제한되는 것과 반대 로 따뜻하고 건조한 날씨 조건이 통근 및 자전거 여행을 장려 하는 것으로 나타났다(Parkin et al., 2008; Heinen et al., 2011; Chardon et al, 2016). 또한, 주말 및 공휴일과 같은 시간적 조건 도 자전거 활동에 영향을 미치는 요인으로 확인되었다(Borgnat et al., 2011; Zhang et al., 2016).
PBSS의 이용은 입지적 요인에 따라서도 다른 패턴을 보인 다. 지역의 인구 규모와 연령대, 지형의 고도와 경사도, 대여소 의 용량, 직장 및 학교를 포함한 주변 시설, 대여소 주변의 토 지이용 현황, 자전거도로 및 철도역과의 근접성 등의 요인들에 의 해서 PBSS 이용 패턴이 다양하게 나타난다(Buck and Buehler, 2012; Maurer, 2012; El-Assi et al., 2017; Guo et al., 2017). 또한, 이용권 종류에 따라서도 이용 패턴의 차이가 발생하기도 한다. 단기 이용자는 레저나 레크레이션 목적으로 이용하는 경 우가 많아서 대여시간이 길고, 주로 주말에 이용하는 패턴이 두 드러지는 것으로 나타났다(Buck et al., 2013; O'Brien et al., 2014). 반면에 장기 이용자의 경우에는 주로 통근 시간에 짧게 이용하는 것으로 나타났다. 단기 이용자의 이용률은 공원과의 근접성과 긍정적인 관련이 있다고 보고되기도 하였다(FaghihImani and Eluru 2016). 이처럼 날씨, 입지, 이용목적과 같은 조건들은 자전거 이용 패턴을 설명하는 데 중요한 역할을 하고 있음을 알 수 있다.

전 세계적으로 $\mathrm{PBSS}$ 의 보급이 활성화되면서 다양한 도시민 의 수요를 반영한 연구들이 이루어져 왔으나, 국내에서는 통근 통학 패턴에 집중된 연구가 주로 이루어져 왔다. 하지만, 국내 에서도 PBSS가 일상생활에서 밀접하게 이용되고 있으므로 보 다 다양한 PBSS 수요를 파악하여 정책 및 운영에 반영할 필요 성이 있다. 본 논문은 서울시 여의도 지역에서 발생하는 PBSS 이용 패턴을 기반으로 대여소를 유형화하고, 유형별 특징을 분 석하는 것을 목적으로 한다. 이는 PBSS 이용에 대한 수요를 유 형에 따라 시간 및 공간적으로 파악함으로써 효과적인 PBSS 
운영이 이루어질 수 있도록 기초자료를 제공하는 것에 의의가 있다.

\section{II. 선행연구}

\section{PBSS의 등장과 발전}

공공에서 제공하는 자전거 공유 시스템(PBSS)은 1965년 네 덜란드의 암스테르담에서 처음 시도되었으나, 파손과 도난으로 인해 성공적이지 못했다. 암스테르담의 첫 시도 이후 30 년이 지난 1995년에서야 덴마크의 수도 코펜하겐에서 'Bycyklen'과 'City Bikes'와 같이 동전을 이용한 자전거 공유시스템이 도입되 었지만, 도난과 기물 및 시설물 파손의 문제점을 개선하지는 못 했다(Shaheen et al., 2010).

$\mathrm{PBSS}$ 가 급격하게 증가한 계기는 1996년 영국의 포츠머스 대학교에서 실시된 이용자 정보의 디지털 등록을 통한 소규모 자전거 공유 프로그램의 시도였다. 이들이 만든 'Bikeabout'은 도난 문제에 대한 해결책을 최초로 제시한 프로그램으로 자전 거를 대여하기 위해서는 이용자가 개별화된 마그네틱 카드를 사용해야 했다. 1998년 프랑스 렌(Rennes)에서는 세계 최초로 도시 규모의 자전거 공유 프로그램인 'Vélo à la Carte'가 운영 되었다. 이용자들은 마그네틱 카드 및 RFID(Radio Frequency IDentification) 기술을 이용하여 25개 정류장에서 200대의 자 전거를 무료로 이용할 수 있었다. 2005년에는 프랑스 리옹시에 서 1,500대 규모의 스마트 자전거 공유시스템인 'Vélo'v'가 출 시되었고, 2007년 파리에서는 6,000대 규모의 'Vélib' 시스템을 출시하면서 대도시에서의 공유자전거 시스템의 시작을 알렸다. 파리의 'Vélib'는 지속적으로 성장하여 2015년에는 18,000여 대 의 자전거를 운영하는 시스템이 되었다(Shaheen et al., 2010).

2010년에는 호주의 멜버른('Melbourne Bike Share') 과 브리 즈번('CityCycle')에서도 호주 최초의 자전거 공유시스템이 등 장했으나, 호주의 엄격한 헬멧 법으로 낮은 이용률을 보이다가 2013년에 정부가 헬멧을 자전거에 부착해 무료로 제공하면서 이용률이 증가하였다(Fishman et al., 2015). 스페인 바르셀로 나의 'Bicing'은 최초로 국가 단위로 확대된 공유자전거 시스템 으로 2013년 기준으로 스페인 132개의 도시에서 이용하고 있는 대규모 자전거 공유시스템으로 성장했다. 그밖에도 미국 워싱 턴DC의 'SmartBike DC', 캐나다 몬트리올의 'Bixi'가 도입되었 으며, 2013년에 도입된 뉴욕의 'Citi Bike'는 최초로 공적자금이 아닌 기업 후원금으로 설립되었다(City Lab, 2020). 최대 공유 자전거 시장인 중국에서는 'ofo小黃車(소황차)', 'mobike'가 점 유율 1, 2위로 2017년 말까지 자전거 이용자가 총 2억 2천만 명 을 초과하였다(KITA, 2018).

국내에도 2008년 창원시를 시작으로 순천시, 대전시, 고양시,
서울시, 세종특별자치시에 PBSS가 도입되었으며, 그중에서 서 울시 '따릉이'는 2010년 시범사업을 거쳐 2015년 9월에 시작되 었다. 2019년도 7월 기준으로 서울시 '따릉이'는 콜센터 1개소, 지역센터 13 개소, 보관소 3 개소의 운영관리 시설과 자전거 배 송(94대) 및 정비(6대)를 위한 차량이 서울시 전 지역을 서비 스하고 있다. 총 283 명의 인력 중 220 명이 배송 및 정비 인력으 로 현장에 인력이 집중되어 운영되고 있다 ${ }^{1)}$.

\section{PBSS의 데이터를 이용한 연구}

PBSS가 처음 도입된 지 50년이 지났지만 IT기술과 접목되 면서부터 데이터의 구축과 분석이 가능해졌다. 그동안 PBSS에 관련한 연구는 환경적 이점과 건강효과에 관한 연구가 주를 이 뤄왔다. 캐나다 몬트리올의 자전거 공유 체계는 2009년 5월에 시작된 이래로 130 만 킬로그램의 온실가스를 절약한 것으로 확 인되었으며(Demaio, 2009), 여러 도시를 대상으로 연구한 결과, $\mathrm{PBSS}$ 가 도시의 탄소 배출량을 줄이고, 교통혼잡을 줄이고 있 는 것이 여러 도시에서 확인되었다(Demaio, 2009; Shaheen et al., 2010). 또한, 자전거 공유가 개인의 체력을 향상시키고, 심 장 질환 및 암 위험 감소와 같은 다양한 건강 문제에 기여하는 것으로 나타났다(Davis and Cavill, 2007).

$\mathrm{PBSS}$ 의 데이터를 이용한 연구는 IT가 접목된 3세대부터 실 시간으로 사용량 데이터에 접근할 수 있게 되었다. 1965년 이 래로 PBSS는 1세대 무료 자전거 시스템, 2세대 코인 결제를 적용한 시스템, 3세대에 들어서는 IT기반 시스템을 통합했으며, 가장 최근인 4세대의 수요 반응형 시스템을 도입했다(Demaio, 2009; Shaheen et al., 2010). 특히, 모바일 장치를 통해 수집된 정보는 개인 이용자에 대한 이해를 높이고, 이용자들에게 위치 기반 실시간 여행 정보를 제공함으로써 자전거의 운영관리 측 면에 도움이 되고 있다.

$\mathrm{PBSS}$ 데이터를 이용하여 시공간적 패턴을 분석하는 연구들 이 꾸준히 이루어지고 있다. 대표적으로 Froehlich et al.(2009) 는 스페인 바르셀로나의 'Bicing'을 대상으로 대여소에서 수집 된 이용자 위치, 시간 데이터를 이용하여 이용 패턴을 조사하 였으며, Wood et al(2011)은 출발지와 도착지 정보를 기반으 로 $\mathrm{PBSS}$ 의 복잡한 시공간 이용 패턴을 시각화하는 것을 시도 하였다. 국내에서는 PBSS 이용량과 입지적 특성과의 관계를 분석한 연구가 주로 이루어졌다. 서울시를 대상으로 한 연구에 서는 대여소가 완만한 경사, 많은 교통량, 자전거 우선도로, 보 행자 겸용도로, 지하철 출입구, 공공시설과 대학교에 가까울수 록 PBSS 대여 및 반납 건수가 높은 것으로 나타났다(Sa and Lee, 2018). 대전시를 대상으로 한 연구에서는 공원, 지하철역. 대학교 인근 대여소에서 PBSS 이용률이 높은 것으로 나타났 으며, 주말에 공원 주변 대여소의 이용률이 높은 것으로 보아, 
PBSS의 주말 이용이 레저를 주목적으로 한다는 것을 제시하 였다(Do and Noh, 2014). 또한, 서울시 대표적인 주거업무 중 심 지역인 여의도와 상암지구를 대상으로 한 연구에서는 점심 시간 대 공원 주변 대여소 이용량이 증가하는 현상이 발생하는 것을 확인하였다(Jang et al., 2016). 자전거도로의 물리적 현황 도 자전거 이용에 중요한 요소로 작용하였다. 녹시율이 높을수 록 자전거도로에서의 자전거 이용의 안정성과 쾌적성이 높게 평가되었으며, 반대로 녹시율이 낮고, 불법 주·정차가 이루어지 며, 노면 표시가 부재할수록 자전거 이용이 열악한 환경으로 평가되었다(Moon et al., 2014). 이처럼 PBSS 데이터를 이용한 연구들은 이용정보에 대한 시간적, 공간적 패턴을 분석함으로 써 PBSS 관리체계의 개선점을 제안하거나 다양한 도시의 특 성을 반영하는 연구가 이루어지고 있다.

\section{III. 연구자료와 방법}

\section{1. 연구자료}

본 연구는 서울시가 운영하는 PBSS인 '따릉이'를 대상으로 한다. 서울시 PBSS는 2010년 11월 자전거 440대를 시작으로 시범 운영되었으며, 2019년 6 월 기준, 1,540 개 대여소에 25,000 대(거치대 19,292개)의 자전거가 운영되고 있다. 서울시 PBSS 는 자전거 관련 법과 조례 ${ }^{2}$ 에 의해서 만들어졌으며, 서울시설 관리공단이 운영 - 관리하고 있다. 서울시설관리공단은 PBSS의 브랜드를 '따릉이'로 명명하고, 시민들에게 스마트폰을 이용하 여 쉽게 이용하고 결제할 수 있도록 시스템을 구축했다. 서울시 $\mathrm{PBSS}$ 의 핵심은 자전거와 자전거에 부착된 단말기에 있다. 단 말기에서 생성된 데이터는 실시간으로 통합관제 시스템으로 전송되어, 도난방지와 함께 대여소별 자전거 수량을 조절하는 역할을 하는 데 도움을 주고 있다. 이용자는 인터넷과 모바일 어플리케이션으로 개인인증과 결제를 완료한 뒤, 카드나 스마 트폰을 이용하여 자전거를 대여할 수 있다. 이용권은 '정기권 일일권'으로 구분되며, ' 1 일 · 1 개월 - 6 개월 · 1 년'으로 이용이 가 능하다. 서울시 PBSS는 2019년 7월 현재까지 약 150 만 회원이 약 2,700 만 건(일 평균 18,987 건)을 이용하였으며, 평균 이용시 간은 27분, 평균 이용 거리는 $4.0 \mathrm{~km}$ 로 확인되었다.

서울시 공공자전거 이용 자료는 서울시에서 제공하는 온라 인 '서울 열린데이터 광장'의 '서울특별시 공공자전거 대여이력 정보'를 검색한 후 2018년 01월 01일부터 12월 31일까지의 자 료를 수집하였다. 자전거대여소 위치정보는 2019년 5월에 작성 된 '서울특별시 공공자전거 대여소 정보' 자료를 사용하였다. 총 9,988,089건의 대여이력 정보를 수집할 수 있었으며, 속성으 로는 '자전거번호', '대여일시', '대여소번호', '대여소명', '대여거 치대', '반납일시', '반납대여소번호', '반납대여소명', '반납거치
대', '이동시간', '이동거리' 등이 포함되었다. 다음으로는 전체 PBSS 이용 자료를 대여소별로 분류함으로써 위치에 기반한 PBSS 이용 데이터를 구축할 수 있었다. 마지막으로 대상지인 여의도 내 위치한 31 개 대여소에서 발생한 대여(430,682건), 반 납(408,414건) 정보를 추출하여 최종분석 자료를 구축하였다.

\section{2. 연구 대상지}

대상지는 여의도(서울특별시 영등포구 여의도동)를 선정하 였다(Figure 1 참조). 여의도는 업무 및 상업지구, 주거지구, 공 원 및 녹지가 명확하게 구분된 지역으로 토지이용 유형에 따라 나타나는 PBSS 이용 패턴을 분석하기 적합하다. 또한, 여의도 전체 면적이 공원 및 녹지로 둘러싸여 있고, 자전거도로가 대 상지 전반에 갖추어져 있어 자전거 이용 패턴을 볼 수 있는 대 표적인 지역이다. 대상지의 주요 특징은 다음과 같다. 상업지구 는 북서쪽에 위치한 공공시설인 국회의사당을 포함하여 북쪽 과 남쪽에 소규모로 분포하고 있으며, 업무지구는 중앙, 주거시 설은 대부분 아파트로 남쪽과 동쪽에 분포한다. 공원 및 녹지 는 여의도공원이 여의도 중앙에 긴 선형으로 위치하고 있으며, 여의도공원의 앙쪽 끝은 여의도 한강공원과 샛강생태공원으로 연결되어 있다. 특히, 북동쪽으로 한강과 맞닿아 있는 여의도 한강공원은 서울시 11 개 한강공원 중에서도 가장 이용률이 높 다. 그 밖에도 여의도는 지하철 5 호선, 9 호선이 통과하고, 서강 대교, 마포대교, 원효대교가 연결되어 있어 접근성이 뛰어난 장 점이 있다.

\section{3. 연구의 방법}

연구의 흐름은 크게 4 가지 단계로 구분된다(Figure 2 참조). 첫째, 서울시 공공자전거 대여이력 자료는 대여소 번호를 포함 하고 있으나 위치정보를 제공하지 않기 때문에, 서울시 공공자 전거 대여이력 9,988,089건을 위치정보를 알 수 있는 1,540 개의 대여소로 분류하였다. 둘째, 구축된 PBSS 데이터에서 연구 대 상지인 여의도에 해당하는 자료만 추출하였다. 여의도에 위치 한 총 31 개 대여소에서 대여 약 43 만건, 반납 약 41 만건의 대여 이력이 발생하였으며, 이를 PBSS 이용패턴 분석을 위한 최종 자료로 구축하였다. 셋째, PBSS 이용패턴 분석방법으로는 시 계열분석과 공간분석을 사용하였다. 시계열분석에서는 대여소 별 요일/연간 이용량 변화를 분석하였으며, 공간분석에서는 대 여소 입지에 따른 이용량 변화를 분석하였다. 넷째, 여의도 내 31개 PBSS 대여소를 주중에 이용률이 높은 대여소, 주말에 이 용률이 높은 대여소, 주중/주말 이용률이 유사한 대여소로 유 형을 구분하여 유형별 특징을 비교 분석하였다. 자료의 처리와 분석은 프로그래밍 언어 Python 3.7과 공간정보시스템 QGIS 3.4 를 사용하고, 통계분석은 SPSS 25.0 을 사용하였다. 


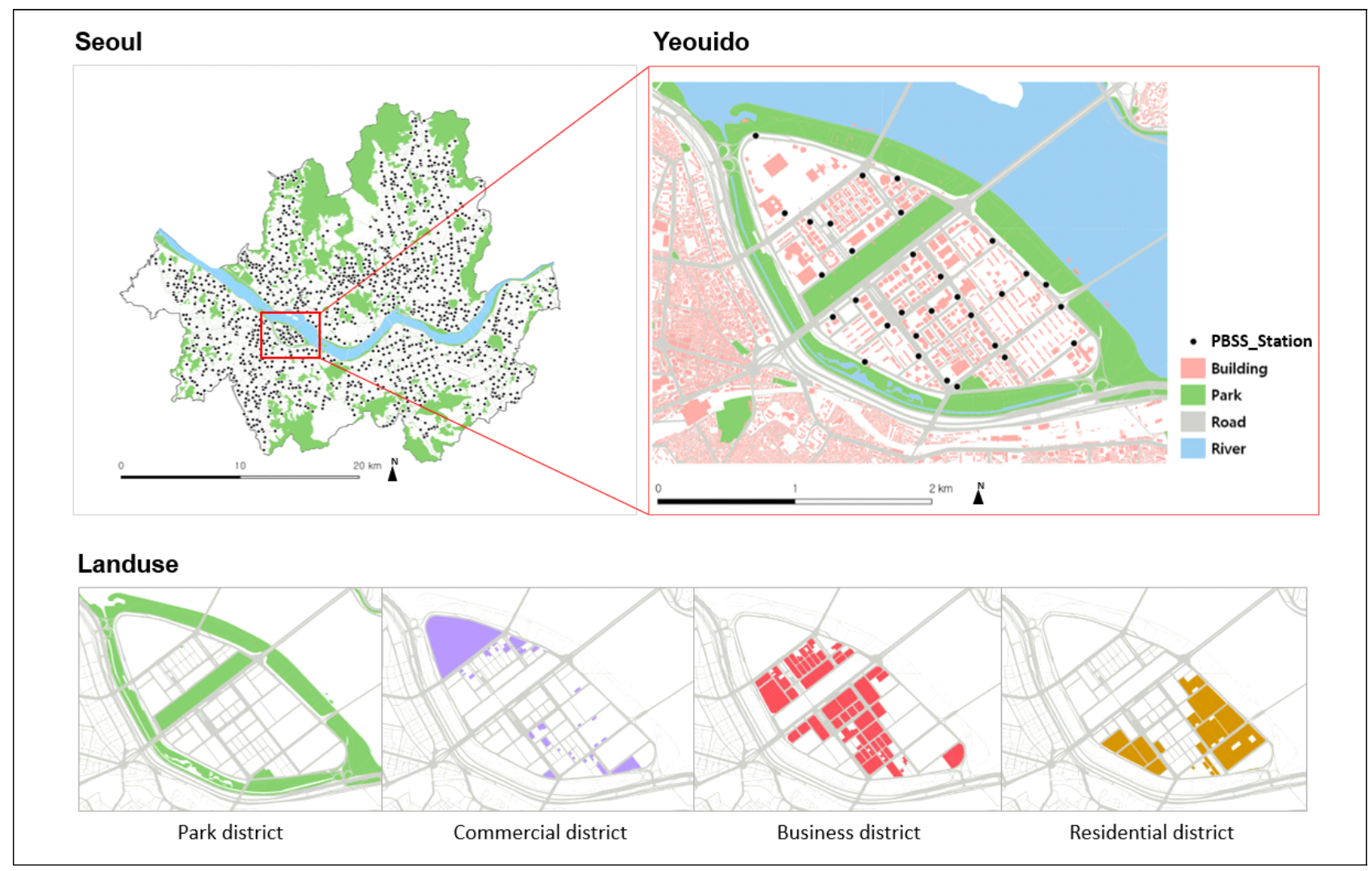

Figure 1. Research site.

Source: Korea National Spatial Data Infrastructure Portal Open API(http://openapi.nsdi.go.kr/), Land Characteristic Space Information (Yeongdeungpo-gu), 2019.10.23. updated data, Modified.

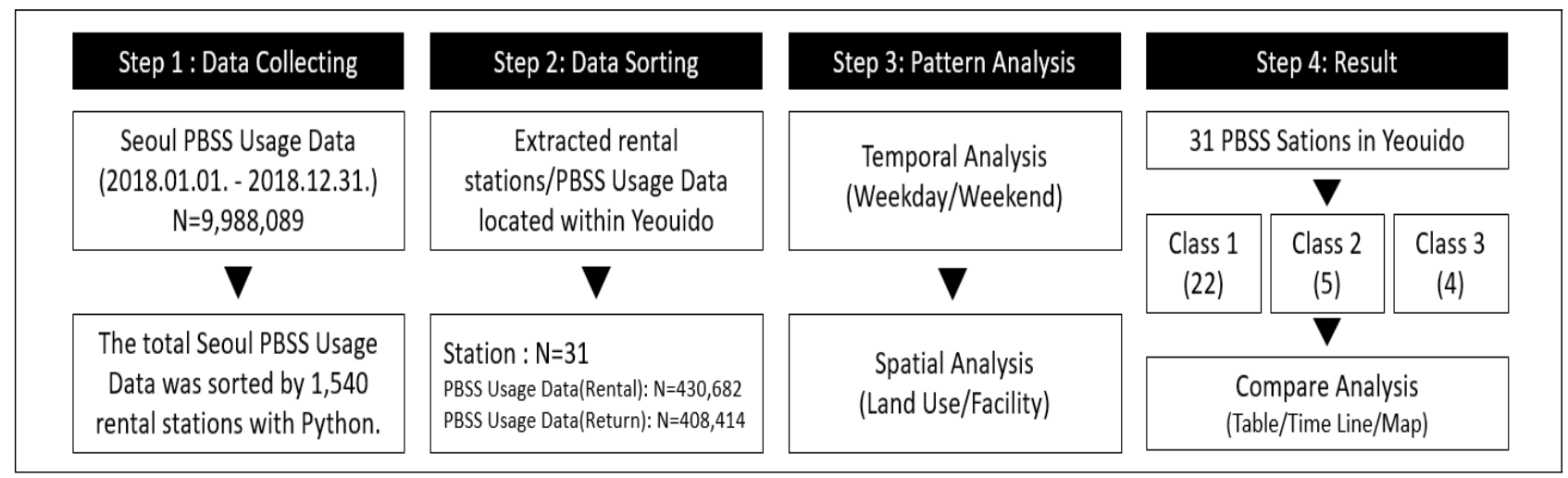

Figure 2. Research flow.

\section{N. 연구 결과}

\section{1. 여의도 전체 PBSS 이용 패턴 분석}

\section{1) 대여소별 여의도 PBSS 이용 패턴}

2018년도 여의도의 PBSS 총이용량은 서울시 전체 PBSS 이 용량 9,988,089건 중 430,682건으로 약 4.3\%에 해당하지만, 대 여소 수의 경우에는 서울시 전체 1,540 개 중 31 개로 $2 \%$ 에 해당
하여 여의도에서의 PBSS 이용이 대여소 개소수에 비해 이용 량이 많은 것을 알 수 있다 세부적으로 여의도 내에서 발생한 대여소별 PBSS 이용률은 다음과 같다(Table 1 참조). 여의도 에서 가장 이용률이 높은 대여소는 '여의나루역 1 번출구 앞' 대 여소로 여의도 총 이용건수 중 대여 $15.9 \%$, 반납 $16.0 \%$ 에 해당 한다. '여의나루역 1 번 출구 앞' 대여소는 지하철 5 호선 '여의나 루 역'에 위치하고 여의도 한강공원 출입구와도 연결되어 있다. 두 번째로 높은 이용률을 보이는 대여소는 'IFC몰' 대여소로 
Table 1. PBSS usage of Yeouido district(31 stations)

\begin{tabular}{|c|c|c|c|c|c|c|c|}
\hline & \multirow{3}{*}{ Bike station number } & \multicolumn{6}{|c|}{ PBSS } \\
\hline & & \multicolumn{2}{|c|}{ Dock } & \multicolumn{2}{|c|}{ Rental instances } & \multicolumn{2}{|c|}{ Return instances } \\
\hline & & $\mathrm{n}$ & $\%$ & $\mathrm{n}$ & $\%$ & $\mathrm{n}$ & $\%$ \\
\hline 1 & 200(국회의원회관) & 20 & 3.6 & 5,290 & 1.2 & 4,836 & 1.2 \\
\hline 2 & 201(진미파라곤 앞) & 15 & 2.7 & 11,490 & 2.7 & 11,817 & 2.9 \\
\hline 3 & 202(국민일보 앞) & 30 & 5.4 & 20,291 & 4.7 & 21,925 & 5.4 \\
\hline 4 & 203(국회의사당역 3번 출구 옆) & 15 & 2.7 & 12,781 & 3.0 & 12,760 & 3.1 \\
\hline 5 & 204(국회의사당역 5번 출구 옆) & 13 & 2.3 & 9,021 & 2.1 & 8,743 & 2.1 \\
\hline 6 & 205(산업은행 앞) & 20 & 3.6 & 11,463 & 2.7 & 10,989 & 2.7 \\
\hline 7 & 206(KBS 앞) & 35 & 6.3 & 13,305 & 3.1 & 12,711 & 3.1 \\
\hline 8 & 207(여의나루역 1번 출구 앞) & 40 & 7.2 & 68,632 & 15.9 & 65,279 & 16.0 \\
\hline 9 & 209(유진투자증권빌딩 앞) & 12 & 2.2 & 9,826 & 2.3 & 9,731 & 2.4 \\
\hline 10 & 210(IFC몰) & 21 & 3.8 & 30,824 & 7.2 & 31,590 & 7.7 \\
\hline 11 & 211(여의도역 4번 출구 옆) & 13 & 2.3 & 20,757 & 4.8 & 18,584 & 4.6 \\
\hline 12 & 212(여의도역 1번 출구 옆) & 35 & 6.3 & 21,089 & 4.9 & 9,607 & 2.4 \\
\hline 13 & 213(KT앞) & 15 & 2.7 & 13,156 & 3.1 & 11,008 & 2.7 \\
\hline 14 & 214(금융감독원 앞) & 20 & 3.6 & 9,325 & 2.2 & 6,907 & 1.7 \\
\hline 15 & 215(여의도고교 앞) & 10 & 1.8 & 7,303 & 1.7 & 8,157 & 2.0 \\
\hline 16 & 216(삼부아파트1동 앞) & 10 & 1.8 & 10,526 & 2.4 & 10,714 & 2.6 \\
\hline 17 & 217(NH농협은행 앞) & 10 & 1.8 & 13,049 & 3.0 & 14,390 & 3.5 \\
\hline 18 & 218(증권거래소 앞) & 20 & 3.6 & 5,938 & 1.4 & 5,173 & 1.3 \\
\hline 19 & 219(롯데캐슬엠파이어 옆) & 12 & 2.2 & 8,798 & 2.0 & 8,246 & 2.0 \\
\hline 20 & 220(미성아파트 A동 앞) & 30 & 5.4 & 11,452 & 2.7 & 7,873 & 1.9 \\
\hline 21 & 221(여의도초교 앞) & 10 & 1.8 & 11,953 & 2.8 & 13,316 & 3.3 \\
\hline 22 & 222(시범아파트버스정류장 옆) & 12 & 2.2 & 21,526 & 5.0 & 24,028 & 5.9 \\
\hline 23 & 223(진주아파트상가 앞) & 20 & 3.6 & 10,997 & 2.6 & 10,483 & 2.6 \\
\hline 24 & 224(롯데캐슬 앞) & 20 & 3.6 & 13,651 & 3.2 & 13,420 & 3.3 \\
\hline 25 & 225(앙카라공원 앞) & 26 & 4.7 & 8,634 & 2.0 & 6,157 & 1.5 \\
\hline 26 & 226(샛강역 1번 출구 앞) & 20 & 3.6 & 12,208 & 2.8 & 9,169 & 2.2 \\
\hline 27 & 248(초원아파트 앞) & 10 & 1.8 & 13,026 & 3.0 & 15,054 & 3.7 \\
\hline 28 & 249(여의도중학교 옆) & 8 & 1.4 & 10,544 & 2.4 & 13,259 & 3.2 \\
\hline 29 & 260(여의도 마리나선착장 앞) & 15 & 2.7 & 4,751 & 1.1 & 4,460 & 1.1 \\
\hline 30 & 270(증권거래소후문교차로) & 10 & 1.8 & 4,880 & 1.1 & 4,600 & 1.1 \\
\hline 31 & 271(샛강생태공원방문자센터 앞) & 10 & 1.8 & 4,196 & 1.0 & 3,428 & 0.8 \\
\hline & Total & 557 & 100 & 430,682 & 100 & 408,414 & 100 \\
\hline
\end{tabular}

Source : Seoul Bike Rental Information(2018.01.01. 2018.12.31.), Seoul open data plaza(https://data.seoul.go.kr).

대여 $7.2 \%$, 반납 $7.7 \%$ 이 나타나는데, 'IFC몰' 대여소는 대규모 쇼핑몰, 여의도 환승센터(버스), 여의도 공원이 연결되는 곳에 위치한다. 세 번째로 높은 이용률을 보이는 대여소는 총 1,578 세대가 거주하는 시범아파트와 63 빌딩 사이에 위치하고 있는 '시범아파트버스정류장 옆' 대여소로 대여 $5.0 \%$, 반납 $5.9 \%$ 에 해당하였다.

여의도에서 가장 이용률이 낮은 대여소는 '샛강생태공원방문 자센터 앞' 대여소로 대여 $1.0 \%$, 반납 $0.8 \%$ 에 해당하였다. '샛 강생태공원방문자센터 앞' 대여소는 여의도 서쪽 외곽의 샛강
생태공원 입구와 윤중초등학교 사이에 위치한다. 다음으로는 여의도 북쪽에 위치한 '여의도 마리나선착장 앞' 대여소와 중심 업무지구에 위치한 ‘증권거래소 후문교차로' 대여소가 동시에 대여 $1.1 \%$, 반납 $1.1 \%$ 로 낮은 이용률을 보였다. 하지만, '여의 도 마리나선착장 앞' 대여소에는 자전거 거치대가 15 개인 것에 비하여 '증권거래소후문교차로' 대여소에는 10 개가 설치되어 있는 것에서 차이가 있다.

여의도에 위치한 PBSS 대여소별 2018년도 1년간의 총 이용 건수 분석결과, 이용률이 높은 대여소는 지하철 출입구, 버스 
환승센터, 대형 쇼핑몰, 대규모 아파트, 대형공원의 인프라가 갖추어진 곳에 위치하는 것을 확인할 수 있었다. 반면에, 이용 률이 낮은 대여소는 접근성이 떨어지는 외곽에 위치하거나, 업 무지구에서도 대중교통시설과 인접하지 않은 곳에 위치하는 것을 확인하였다. 또한, PBSS 시설인 거치대(Dock)의 양과 이 용률이 일치하지 않는 것을 알 수 있었다. 예를 들어 'IFC몰' 대여소의 경우에는 $7.2 \%$ 의 높은 대여 이용률을 보이지만, 거치 대 수는 $3.8 \%$ 로 차이가 있는 것을 확인할 수 있었다.

2) 시계열 변화에 따른 PBSS 이용 패턴

시계열 분석은 요일별로 변화하는 PBSS 이용에 집중하여 연구를 진행하였다. 선행연구에서 제시된 것과 같이 주중 (Weekday), 주말(Weekend)의 PBSS 이용은 다르게 나타난
다. 주중에는 통근통학이 주로 발생하는 오전 8시와 오후 6시 에 이용이 집중되어 발생하고, 주말에는 오후 2 6시에 걸쳐 활발하게 PBSS가 이용되는 것으로 보고되었다(Zhou, 2015). 본 연구에서는 여의도에 위치한 31 개 대여소의 주중과 주말에 발생하는 PBSS 대여량을 기반으로 유형별 이용 패턴을 분석 하였으며, 주중 이용량이 높은 22개 대여소와 주말 이용량이 높은 5 개 대여소, 주중/주말 모두 이용량이 유사한 4 개 대여소 를 구분할 수 있었다(Figure 3 참조). 주중과 주말 이용량 비율 로 보면 주중 이용량이 높은 22 개 대여소(이하 유형 1)는 주중 이용량이 주말 이용량 대비 3 배 이상, 주말 이용량이 높은 5 개 대여소(이하 유형 2)는 약 1 2배, 주중/주말 이용량이 유사한 4 개 대여소(이하 유형 3)는 약 2 3배의 차이가 나타났다. 유 형 1 은 월요일부터 금요일까지 일정한 이용량을 보이다가 토요

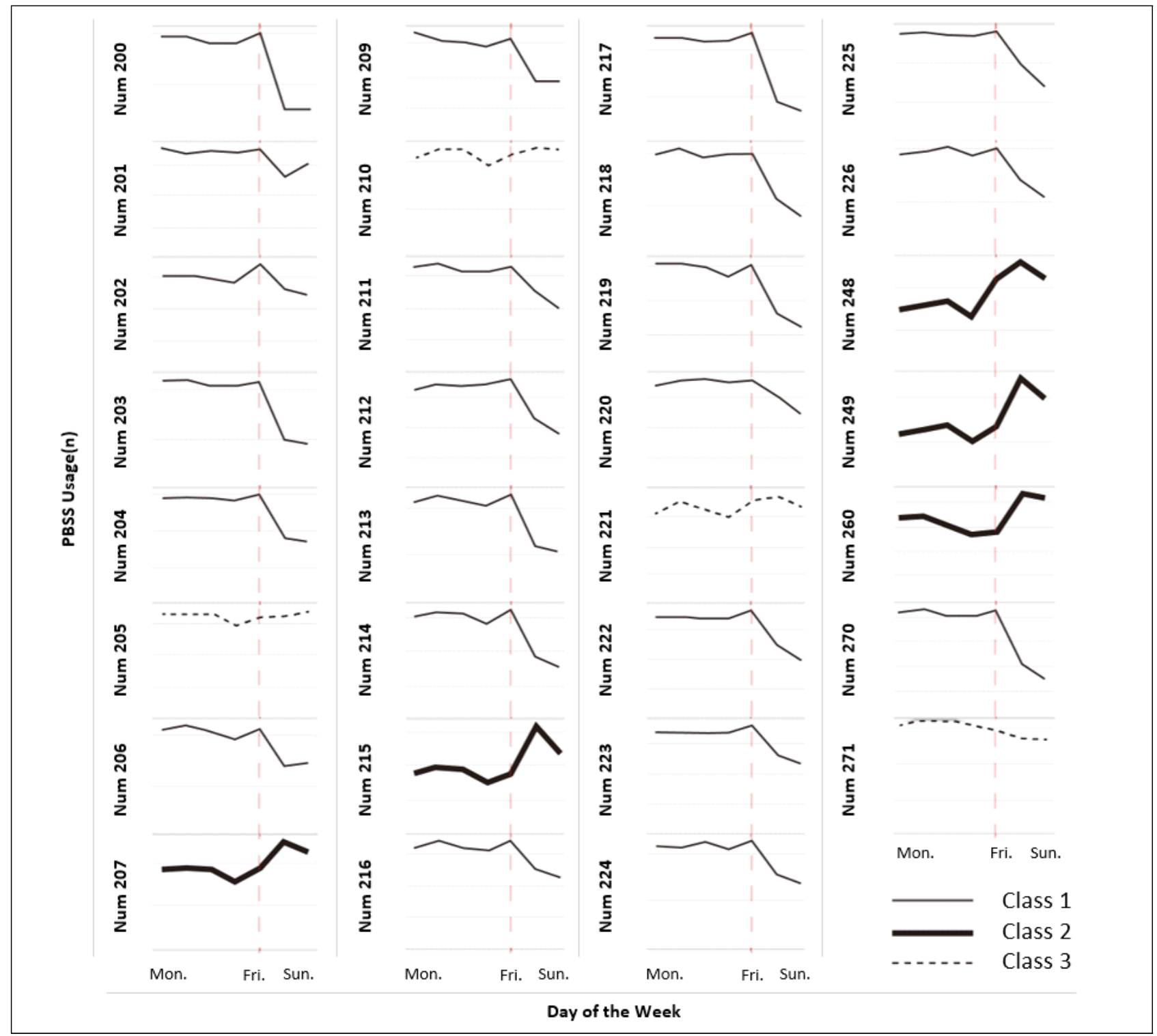

Figure 3. PBSS usage(weekday/weekend) of 31 PBSS stations(2018.01.01. 2018.12.31.). 
일부터 이용량이 급격히 줄어드는 경향을 보였으며, 유형 2는 수요일에 이용량이 가장 줄어들고 목요일부터 다시 반등하는 경향이 나타났다. 유형 3 은 요일에 상관없이 다른 유형에 비해 비교적 일정한 이용률이 나타났다.

\section{2. 유형별 PBSS 대여소의 이용 패턴 특징}

2018년도 한 해 동안 여의도 내에서 발생한 PBSS 이용 패턴 을 유형 1(22개 대여소), 유형 2(5개 대여소), 유형 3(4개 대여 소)으로 구분하여 분석한 결과는 다음과 같다. 여의도 내 전체 PBSS 대여 건수 430,682건을 유형별로 나누어 보면 유형 1이 $62.2 \%$, 유형 2 가 $24.2 \%$, 유형 3 이 $13.6 \%$ 를 차지한다. 대여소 개소 비율에서 유형 1 이 $71.0 \%$, 유형 2 가 $16.1 \%$, 유형 3이 $12.9 \%$ 를 차지하는 것과 비교하면, 유형 2가 대여소 개소 숫자 에 비해 활발하게 이용되고 있음을 알 수 있다. 연간 이용량을 비교해 보면 일 년 중 가장 많은 이용량은 유형 1 의 경우에는 9월 17일 월요일(1,664건), 9월 12일 수요일(1,643건), 10 월 4일 목요일 (1,637건) 순으로 대부분 주중 이용이었다. 반면에, 유형 2 의 경우에는 9 월 29 일 토요일(1,240건), 한글날인 10 월 9 일 화 요일(1,180건), 추석 명절 연휴인 9월 25일 토요일(1,163건) 순 으로 가을철 공휴일과 주말에 PBSS 이용률이 높은 것으로 나 타났다. 유형 3 은 1 년 전체적으로는 주중/주말 이용량이 유사 하나, 이용량 순위가 높은 날짜를 살펴보면, 대부분 휴일 또는 주말로 확인되었다(Table 2 참조).

연간 이용량의 변화에서는 유형 1 의 경우 평일(월요일 금 요일) 동안 이용률이 높고, 주말(토요일, 일요일)에 이용률이
급락하는 것이 반복되는 양상이 나타났다. 계절적으로는 겨울 에 이용률이 저조하고, 3 월을 기점으로 이용률이 증가하다가 가 을인 9 10월에 이용률이 가장 높을 것을 확인할 수 있다. 장마 철과 혹서기인 7 8월에는 이용률이 감소하는 것으로 보아, 자 전거 이용률은 날씨에 영향을 받는 것을 추측할 수 있다. 유형 2 의 이용 패턴은 봄철과 가을철에 집중되었으며, 주말과 공휴일 의 이용량이 많았다. 유형 3 의 이용 패턴은 유형 1 과 유형 2 보다 변동량이 적었으나, 유형 2에 가까운 패턴이 나타났다(Figure 4 참조).

이용거리와 이용시간에 따른 PBSS 이용 패턴에서도 유형별 차이가 나타났다(Table 3 참조). 평균 이동거리의 경우에는 유 형 1 약 $4.3 \mathrm{~km}$, 유형 2 약 $7.2 \mathrm{~km}$, 유형 3 약 $5.3 \mathrm{~km}$ 를 이동하여 유형 2가 다른 유형에 비해서 장거리로 이용되는 것을 확인하 였다. 이용시간의 경우에는 유형 1 평균 25.6분, 유형 2 평균 45.8분, 유형 3 평균 33.1분으로 유형 2가 유형 1에 비해서 약 20 분 길게 이용되는 것으로 나타났다. 최소 이용시간과 거리는 모두 0 으로 처리되었는데, 이는 통신장애 및 전산오류로 분석 에서는 제외하였다.

대여와 반납 패턴에 따라서도 유형별 차이가 나타났다. (i) 대 여-반납장소가 같은 경우, (ii) 대여-반납장소가 같은 경우를 제 외한 여의도 내에서만 이동한 경우, (iii)여의도 내부에서 대여 하였으나 여의도 외부에서 반납한 경우로 나누어 볼 수 있다 (Table 4 참조), 유형 1은 전체 이용량 중 각각 (i) $8.1 \%$, (ii) $50.5 \%$, (iii) $41.4 \%$ 로 나타났으며, 유형 2는 (i) $24.9 \%$, (ii) $28.4 \%$, (iii) $46.8 \%$, 유형 3은 (i) $13.8 \%$, (ii) $43.9 \%$, (iii) $42.2 \%$ 로 나타났다. 종합적으 로 여의도 내에서만 수요와 공급이 발생한 패턴(i, ii)은 유형

Table 2. PBSS usage frequency by date(2018.01.01. 2018.12.31.)

\begin{tabular}{|c|c|c|c|c|c|c|c|c|c|}
\hline \multirow[b]{2}{*}{ Rank } & \multicolumn{3}{|c|}{ Class 1 (22 stations) } & \multicolumn{3}{|c|}{ Class 2(5 stations) } & \multicolumn{3}{|c|}{ Class 3 (4 stations) } \\
\hline & Date & $\begin{array}{c}\text { PBSS } \\
\text { usage }(n)\end{array}$ & Holiday & Date & $\begin{array}{c}\text { PBSS } \\
\text { usage }(\mathrm{n})\end{array}$ & Holiday & Date & $\begin{array}{c}\text { PBSS } \\
\text { usage }(n)\end{array}$ & Holiday \\
\hline 1 & 2018-09-17 Mon & 1,664 & - & 2018-09-29 Sat & 1,240 & - & 2018-10-09 Tue & 587 & $\begin{array}{c}\text { Hangeul Proclamation } \\
\text { Day }\end{array}$ \\
\hline 2 & 2018-09-12 Wed & 1,643 & - & 2018-10-09 Tue & 1,180 & $\begin{array}{c}\text { Hangeul Proclamation } \\
\text { Day }\end{array}$ & 2018-09-26 Wed & 578 & $\begin{array}{l}\text { Chuseok(Korean } \\
\text { Thanksgiving Day) }\end{array}$ \\
\hline 3 & 2018-10-04 Thu & 1,637 & - & 2018-09-25 Tue & 1,163 & $\begin{array}{l}\text { Chuseok(Korean } \\
\text { Thanksgiving Day) }\end{array}$ & 2018-10-03 Wed & 528 & $\begin{array}{c}\text { National Foundation } \\
\text { Day }\end{array}$ \\
\hline 4 & 2018-09-11 Tue & 1,626 & - & 2018-10-03 Wed & 1,145 & $\begin{array}{c}\text { National Foundation } \\
\text { Day }\end{array}$ & 2018-09-29 Sat & 484 & - \\
\hline 5 & 2018-09-27 Thu & 1,607 & - & 2018-09-08 Sat & 1,141 & - & 2018-09-25 Tue & 473 & $\begin{array}{l}\text { Chuseok(Korean } \\
\text { Thanksgiving Day) }\end{array}$ \\
\hline 6 & 2018-09-10 Mon & 1,603 & - & 2018-09-26 Wed & 1,083 & $\begin{array}{l}\text { Chuseok(Korean } \\
\text { Thanksgiving Day) }\end{array}$ & 2018-09-09 Sun & 443 & - \\
\hline 7 & 2018-09-13 Thu & 1,579 & - & 2018-09-09 Sun & 1,035 & - & 2018-09-08 Sat & 417 & - \\
\hline 8 & 2018-09-28 Fri & 1,549 & - & 2018-09-30 Sun & 948 & - & 2018-05-19 Sat & 401 & - \\
\hline 9 & 2018-09-07 Fri & 1,528 & - & 2018-05-19 Sat & 916 & - & 2018-10-07 Sun & 387 & - \\
\hline 10 & 2018-09-05 Wed & 1,513 & - & 2018-04-29 Sun & 905 & - & 2018-05-20 Sun & 384 & - \\
\hline
\end{tabular}




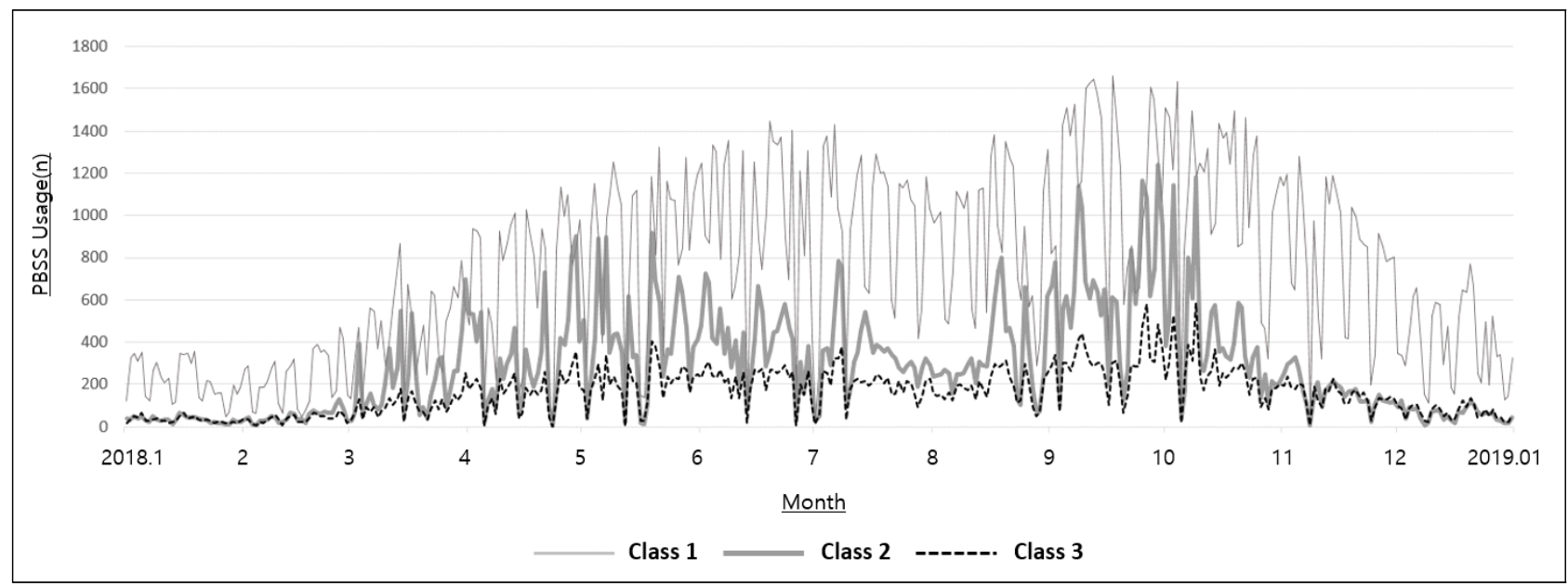

Figure 4. PBSS usage pattern(2018.01.01. 2018.12.31.).

Table 3. Patterns of the distance and time(2018.01.01. 2018.12.31.)

\begin{tabular}{c|c|c|c|c}
\hline \multicolumn{2}{c|}{ Contents } & Class 1(22 stations) & Class 2(5 stations) & Class 3(4 stations) \\
\hline \multirow{2}{*}{$\begin{array}{c}\text { Distance } \\
(\mathrm{m})\end{array}$} & Mean & 4,331 & 7,235 & 5,299 \\
\cline { 2 - 5 } & Max & 255,680 & 254,350 & 255,880 \\
\hline \multirow{2}{*}{$\begin{array}{c}\text { Time } \\
(\mathrm{min})\end{array}$} & Mean & 26 & 46 & 33 \\
\cline { 2 - 5 } & Max & 1,440 & 996 & 1,087 \\
\hline
\end{tabular}

Table 4. Patterns of the rental and return(2018.01.01. 2018.12.31.)

\begin{tabular}{l|c|c|c|c|c|c}
\hline \multirow{2}{*}{ Contents } & \multicolumn{4}{c}{ PBSS Usage } \\
\cline { 2 - 8 } & \multicolumn{2}{c|}{ Class 1(22 stations) } & \multicolumn{2}{c}{ Class 2(5 stations) } & \multicolumn{2}{c}{ Class 3(4 stations) } \\
\cline { 2 - 8 } & $\mathrm{n}$ & $\%$ & $\mathrm{n}$ & $\%$ & $\mathrm{n}$ & $\%$ \\
\hline (i) Rental (in Yeouido) - Return (in Yeouido) : Same station & 21,696 & 8.1 & 25,950 & 24.9 & 8,082 & 13.8 \\
\hline (ii) Rental (in Yeouido) - Return (in Yeouido) : Different station & 135,284 & 50.5 & 29,561 & 28.4 & 25,682 & 43.9 \\
\hline (iii) Rental (in Yeouido) - Return (out Yeouido) & 111,010 & 41.4 & 48,745 & 46.8 & 24,672 & 42.2 \\
\hline Total(n = 430,682) & 267,990 & 100.0 & 104,256 & 100.0 & 58,436 & 100.0 \\
\hline
\end{tabular}

1(58.6\%), 유형 2(53.3\%), 유형 3(57.7\%)으로 모두 전체 이용 량 중 $50 \%$ 대의 점유율을 나타내는 것을 확인할 수 있었다. Jang et al.(2016)의 연구에서 여의도 지구 내에서만 발생한 통 행량이 $90.7 \%$ 로 도출된 것과 비교하면, PBSS 이용이 2018년 도에는 여의도 내부에서 외부지역으로 이동하는 패턴이 늘어 난 것으로 해석할 수 있다.

\section{3. 유형별 PBSS 대여소의 공간 특성}

유형별 PBSS 대여소의 공간 분포는 다음과 같다(Figure 5 참조). 유형 1 에 해당하는 대여소는 주로 여의도 중심의 업무 및 주거밀집지역에 분포하였다. 유형 2에 해당하는 대여소는 여의도 한강공원과 인접한 곳에 5 개의 대여소가 분포하였다. 유형 3에 해당하는 대여소는 유형 2와 같이 공원과 인접한 곳
에 분포하고 있으나, 주중/주말 이용량이 유사한 패턴이 나타 났다. 공원과 인접한 대여소에 대해서 Do and Noh(2014)는 공 유자전거 대여소에서 공원 및 수변공간까지의 거리를 공유자 전거 이용수요에 영향을 주는 요인으로 평가하였으며, Jang et al.(2016)의 연구에서는 공원에 인접한 대여소에서 동일 대여반납 비율과 비정기권의 이용 비율이 높아, 공공자전거가 공원 이용이나 관광목적으로 이용 경향이 있음을 시사하였다.

또한, 공유자전거 이용량과 대중교통 이용량, 자전거도로 길 이도 관련이 있는 것으로 연구되었다(Do and Noh, 2014). 본 연구의 대상지인 여의도에 위치한 주요 대중교통시설은 지하 철 $5 \cdot 9$ 호선에 해당하는 4 개 역이 운영되고 있으며, 여의도 중 심에는 $5 \cdot 9$ 호선 지하철 환승역인 '여의도역'을 중심으로 북쪽 에는 '9호선 국회의사당역', 남쪽으로는 '9호선 샛강역', 동쪽에 는 한강공원과 연결된 지하철 '5호선 여의나루역'이 위치한다. 


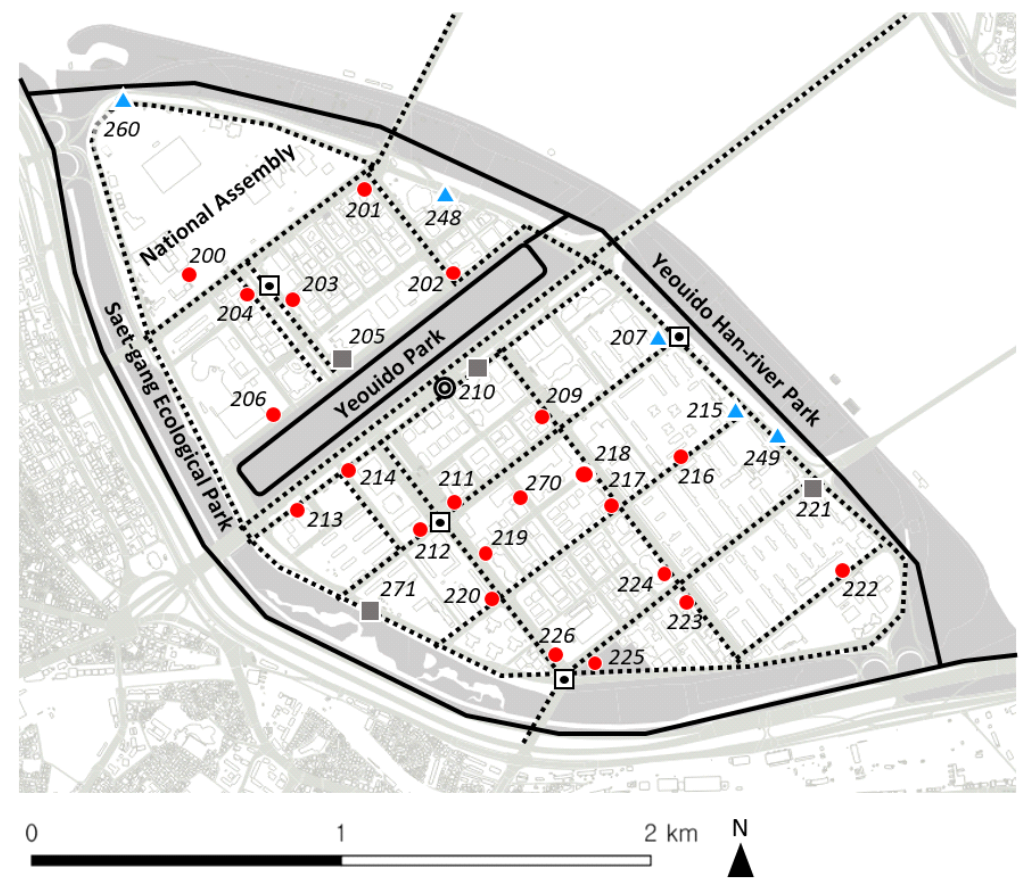

\section{PBSS Station}

- Class 1 (22 Stations)

$\Delta$ Class 2 (5 Stations)

Class 3 (4 Stations)

\section{Facility}

๑) Bus Transfer Center

$\square$ Subway Station

Park

Building

Road

Bike Road

- Exclusive Bicycle Path

Bicycle \& Pedestrian Path

Figure 5. Distribution of PBSS rental stations by 3 types(2018.01.01. 2018.12.31.).

또한, 여의도공원과 인접하여 다양한 노선의 버스들이 정차하 는 '여의도 환승센터'가 위치하고 있다. 자전거도로의 경우에는 편리하게 자전거를 이용할 수 있도록 여의도 전역에 걸쳐서 설 치되어 있다. 자전거도로의 유형별로는 보행 및 자전거 혼용 도로가 공원 외 지역에 설치되어 있으며, 여의도공원, 한강공원, 샛강생태공원에는 자전거 전용도로(2차선)가 설치되어 있다.

특히, 유형 2의 경우에는 대여소 입지가 업무지구보다는 공 원, 주거, 상업지구로 구성되어 있어 평일 직장인들의 출퇴근을 위한 이용보다는 주말에 여가 및 관광을 위한 이용이 있을 것 으로 예상할 수 있다. 하지만, 공원과 인접한 대여소라 하여 같 은 이용 패턴을 나타내는 것은 아니다. 여의도 한강공원의 경 우에는 도로와 한강으로 인해 공간이 분리되어 있고, $56 \mathrm{~km}$ 의 ‘한강종주자전거길'에 포함되어 자전거 여행객을 위한 편의시
설이 잘 갖추어져 있어 출퇴근 목적의 보다는 유형 2의 이용 패턴이 나타나는 것으로 보인다. 여의도공원은 한강공원과 같 이 넓은 오픈스페이스와 자전거 전용도로를 제공하기 때문에 유형 2의 패턴이 나타나기도 하지만, 업무지구와 주요 교통시 설이 인접하고 있어서 유형 1 과 유형 2 의 이용 패턴의 특징이 동시에 나타난다. 반면에 샛강생태공원의 경우에는 생태계 보 호와 생태관찰프로그램을 위해서 자전거 이용이 허용되지 않 는 구간이 있으며, 자전거 전용도로가 있으나 교량이나 생태공 원을 넘어서 접근해야 하는 특징이 있다(Figure 6 참조).

대여소의 입지 특성을 살펴보면 다음과 같다(Table 5 참조). 대여소별 PBSS 주중/주말 이용량의 비율은 유형 1의 경우에 는 주중 이용량이 주말 이용량에 비해서 3 7.9배 많았으며, 유 형 2의 경우에는 $1.4 \sim 1.9$ 배 정도 많은 것으로 나타났다. 유형 3

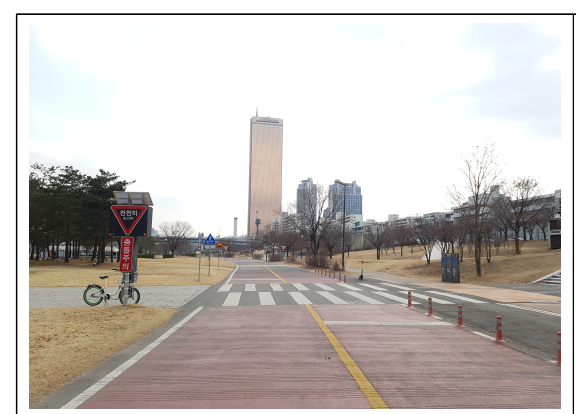

a: Han-river park(Bicycle path)

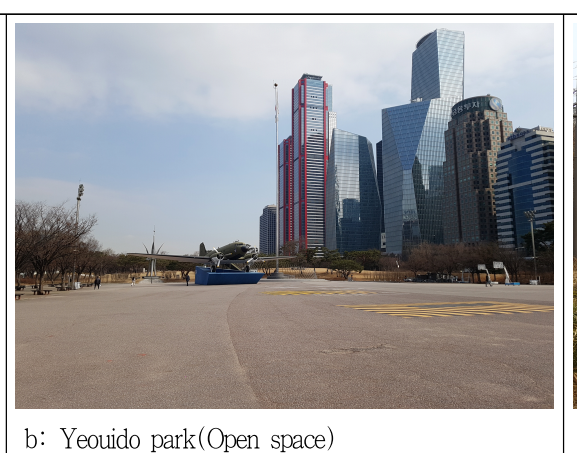

b: Yeouido park(Open space)

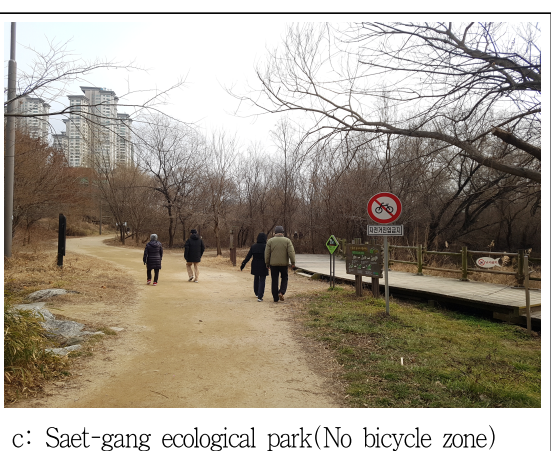

c: Saet-gang ecological park(No bicycle zone)

Figure 6. Characteristics of 3 parks in Yeouido(2018.01.01. 2018.12.31.). 
Table 5. Spatial characteristics of each rental station

\begin{tabular}{|c|c|c|c|c|c|c|c|c|c|c|}
\hline \multirow[b]{2}{*}{ Contents } & \multicolumn{4}{|c|}{ PBSS usage } & \multicolumn{3}{|c|}{ Park } & \multicolumn{2}{|l|}{ Public transportation } & \multirow[b]{2}{*}{ Land use } \\
\hline & Class & \begin{tabular}{|c|}
$\begin{array}{c}\text { Weekday } \\
\text { (n) }\end{array}$ \\
\end{tabular} & \begin{tabular}{|c|}
$\begin{array}{c}\text { Weekend } \\
(\mathrm{n})\end{array}$ \\
\end{tabular} & Ratio ${ }^{*}$ & Main park & \begin{tabular}{|c|}
$\begin{array}{c}\text { Distance for } \\
\text { park gate }(\mathrm{m})\end{array}$ \\
\end{tabular} & \begin{tabular}{|c|}
$\begin{array}{c}\text { Bicycle path } \\
(\mathrm{km})\end{array}$ \\
\end{tabular} & Main public transportation & \begin{tabular}{|c|}
$\begin{array}{c}\text { Distance for } \\
\text { station }(\mathrm{m})\end{array}$ \\
\end{tabular} & \\
\hline 200 & 1 & 4,693 & 597 & $7.9: 1$ & $\begin{array}{l}\text { Saet-gang } \\
\text { ecological }\end{array}$ & 412 & 4.7 & \multirow{2}{*}{ Subway line 9 (National assembly) } & 294 & Commercial \\
\hline 201 & 1 & 8,655 & 2,835 & $3.1: 1$ & $\begin{array}{c}\text { Yeouido } \\
\text { han-river }\end{array}$ & 246 & 5.6 & & 409 & $\begin{array}{c}\text { Business and } \\
\text { commercial }\end{array}$ \\
\hline 202 & 1 & 15,265 & 5,026 & $3.0: 1$ & Yeouido & 67 & 2.4 & (Bus) Yeouido transportation center & 491 & Business and park \\
\hline 203 & 1 & 10,896 & 1,885 & $5.8: 1$ & Yeouido & 332 & 2.4 & \multirow{4}{*}{ Subway line 9 (National assembly) } & 30 & Business \\
\hline 204 & 1 & 7,272 & 1,749 & $4.2: 1$ & Yeouido & 460 & 2.4 & & 28 & Business \\
\hline 205 & 3 & 8,117 & 3,346 & $2.4: 1$ & Yeouido & 66 & 2.4 & & 266 & Business and park \\
\hline 206 & 1 & 10,489 & 2,816 & $3.7: 1$ & Yeouido & 63 & 2.4 & & 438 & Business and park \\
\hline 207 & 2 & 44,903 & 23,729 & $1.9: 1$ & $\begin{array}{c}\text { Yeouido } \\
\text { Han-river }\end{array}$ & 129 & 5.6 & Subway line 5 (Yeouinaru) & 16 & Park and residential \\
\hline 209 & 1 & 7,956 & 1,870 & $4.3: 1$ & $\begin{array}{c}\text { Yeouido } \\
\text { Han-river }\end{array}$ & 564 & 5.6 & \multirow{2}{*}{ (Bus) Yeouido transportation center } & 409 & Business \\
\hline 210 & 3 & 21,670 & 9,154 & $2.4: 1$ & Yeouido & 185 & 2.4 & & 107 & Business and park \\
\hline 211 & 1 & 16,244 & 4,513 & $3.6: 1$ & Yeouido & 418 & 2.4 & \multirow{4}{*}{ Subway line $5 \cdot 9$ (Yeouido) } & 2 & $\begin{array}{c}\text { Business and } \\
\text { residential }\end{array}$ \\
\hline 212 & 1 & 17,084 & 4,005 & $4.3: 1$ & $\begin{array}{l}\text { Saet-gang } \\
\text { ecological }\end{array}$ & 382 & 4.7 & & 28 & $\begin{array}{c}\text { Business and } \\
\text { residential }\end{array}$ \\
\hline 213 & 1 & 10,888 & 2,268 & $4.8: 1$ & Yeouido & 288 & 2.4 & & 524 & Business and park \\
\hline 214 & 1 & 7,660 & 1,665 & $4.6: 1$ & Yeouido & 283 & 2.4 & & 328 & Business and park \\
\hline 215 & 2 & 4,507 & 2,796 & $1.6: 1$ & $\begin{array}{c}\text { Yeouido } \\
\text { Han-river }\end{array}$ & 29 & 5.6 & Subway line 5 (Yeouinaru) & 266 & Park and residential \\
\hline 216 & 1 & 8,153 & 2,373 & $3.4: 1$ & $\begin{array}{c}\text { Yeouido } \\
\text { Han-river }\end{array}$ & 289 & 5.6 & Subway line 5 (Yeouinaru) & 518 & Residential \\
\hline 217 & 1 & 11,501 & 1,548 & $7.4: 1$ & $\begin{array}{c}\text { Yeouido } \\
\text { Han-river }\end{array}$ & 570 & 5.6 & \multirow{4}{*}{ Subway line $5 \cdot 9$ (Yeouido) } & 695 & $\begin{array}{l}\text { Business and } \\
\text { residential }\end{array}$ \\
\hline 218 & 1 & 4,997 & 941 & $5.3: 1$ & Yeouido & 505 & 2.4 & & 521 & $\begin{array}{l}\text { Business and } \\
\text { residential }\end{array}$ \\
\hline 219 & 1 & 7,358 & 1,440 & $5.1: 1$ & Yeouido & 667 & 2.4 & & 194 & $\begin{array}{l}\text { Business and } \\
\text { residential }\end{array}$ \\
\hline 220 & 1 & 8,734 & 2,718 & $3.2: 1$ & $\begin{array}{l}\text { Saet-gang } \\
\text { ecological }\end{array}$ & 613 & 4.7 & & 253 & $\begin{array}{c}\text { Business and } \\
\text { residential }\end{array}$ \\
\hline 221 & 3 & 8,345 & 3,608 & $2.3: 1$ & $\begin{array}{c}\text { Yeouido } \\
\text { Han-river } \\
\end{array}$ & 45 & 5.6 & Subway line 5 (Yeouinaru) & 624 & Park and residential \\
\hline 222 & 1 & 17,114 & 4,412 & $3.9: 1$ & $\begin{array}{c}\text { Yeouido } \\
\text { Han-river }\end{array}$ & 214 & 5.6 & \multirow{5}{*}{$\begin{array}{l}\text { Subway line } 9 \\
\text { (Saet-gang) }\end{array}$} & 971 & $\begin{array}{l}\text { Business and } \\
\text { residential }\end{array}$ \\
\hline 223 & 1 & 8,509 & 2,488 & $3.4: 1$ & $\begin{array}{l}\text { Saet-gang } \\
\text { ecological }\end{array}$ & 305 & 4.7 & & 481 & $\begin{array}{l}\text { Business and } \\
\text { residential }\end{array}$ \\
\hline 224 & 1 & 10,762 & 2,889 & $3.7: 1$ & $\begin{array}{l}\text { Saet-gang } \\
\text { ecological } \\
\end{array}$ & 628 & 4.7 & & 415 & Residential \\
\hline 225 & 1 & 6,956 & 1,678 & $4.1: 1$ & $\begin{array}{l}\text { Saet-gang } \\
\text { ecological } \\
\end{array}$ & 240 & 4.7 & & 25 & Business and park \\
\hline 226 & 1 & 9,728 & 2,480 & $3.9: 1$ & $\begin{array}{l}\text { Saet-gang } \\
\text { ecological }\end{array}$ & 190 & 4.7 & & 76 & $\begin{array}{c}\text { Business and } \\
\text { commercial }\end{array}$ \\
\hline 248 & 2 & 8,207 & 4,819 & $1.7: 1$ & $\begin{array}{c}\text { Yeouido } \\
\text { Han-river }\end{array}$ & 53 & 5.6 & Subway line 9 (National assembly) & 679 & Commercial and park \\
\hline 249 & 2 & 6,151 & 4,393 & $1.4: 1$ & $\begin{array}{c}\text { Yeouido } \\
\text { Han-river }\end{array}$ & 52 & 5.6 & Subway line 5 (Yeouinaru) & 351 & Park and residential \\
\hline 260 & 2 & 3,057 & 1,694 & $1.8: 1$ & $\begin{array}{c}\text { Yeouido } \\
\text { Han-river }\end{array}$ & 121 & 5.6 & Subway line 9 (National assembly) & 1,080 & Commercial and park \\
\hline 270 & 1 & 4,150 & 730 & $5.7: 1$ & Yeouido & 517 & 2.4 & \multirow[b]{2}{*}{ Subway line $5 \cdot 9$ (Yeouido) } & 271 & Business \\
\hline 271 & 3 & 3,119 & 1,077 & $2.9: 1$ & $\begin{array}{l}\text { Saet-gang } \\
\text { ecological }\end{array}$ & 109 & 4.7 & & 466 & Park and residential \\
\hline
\end{tabular}


의 경우에는 2.3 2.9배 차이가 발생하는 것으로 확인되었다. 주중/주말 이용량 차이가 가장 크게 나타나는 200번, 217번, 203 번 대여소는 공원에서 $300 \mathrm{~m}$ 이상 떨어진 업무지역에 위치 하고, 차이가 가장 작게 나타나는 249번, 215번, 248번 대여소 는 공원에서 $100 \mathrm{~m}$ 이내에 위치하는 특징이 있었다.

대여소별 PBSS 이용량(주중, 주말)과 거리(공원입구, 대중 교통시설)에 대한 차이 분석결과에서는 '주말 PBSS 이용량과 '대 여소에서 공원입구까지의 거리'의 유형간 평균 차이가 ANOVA 분석에서 통계적으로 유의미한 것으로 도출되었다(Table 6 , Table 7 참조). ANOVA 분석 결과에 대한 사후검증(Bonferroni 검정)에서는 PBSS 주말 이용량의 경우 유형 2가 다른 유형에 비해 주말 이용량이 많고 유의미한 차이가 있는 것으로 나타났 다. 공원입구까지의 거리의 경우에는 유형 1 이 유형 $2 \cdot 3$ 보다 거리가 멀고 유의미한 차이가 있는 것으로 나타났다. 이처럼 유형 2의 경우에는 공원 입구에서 가까움과 동시에 주말 이용 률이 높아 PBSS 관리에 있어서 공원에 인원이 밀집되는 시기 를 고려하여 시설을 운영할 필요성이 있다. Do and Noh(2014) 의 연구에서는 공원 인근 대여소에서 주중보다 주말 이용수요 가 높은 현상을 레저를 위한 것으로 해석하기도 하였다. 그 외 변수로 설정한 주중 이용률, 대중교통시설에 대한 차이 분석결 과에서는 유형간 통계적으로 유의미한 차이가 없는 것으로 나 타났다. Sa and Lee(2018)는 공공자전거 대여소에서 $100 \mathrm{~m}$ 이 내의 거리에 지하철 출입구가 위치할 때 공공자전거 이용량에 양 $(+)$ 의 영향을 미치는 것을 확인하였지만, 본 연구에서는 대 여소와 지하철 출입구 간의 유의미한 결과가 나타나지 않았다.
이는 $\mathrm{PBSS}$ 이용이 시간 및 환경 조건에 따라 다양한 결과가 도출될 수 있음을 보여준다.

\section{V. 결론 및 제언}

본 연구는 서울시 PBSS 자료를 기반으로 대여소별 유형과 이용패턴을 파악하기 위해 주중/주말 이용률을 기반으로 대여 소를 3개로 유형화하여 특징을 비교 분석하였다. 여의도의 $\mathrm{PBSS}$ 이용량은 서울시 전체에서 $4.3 \%$ 에 해당하여 대여소 규 모 $2 \%$ 보다 높은 것으로 나타났다. 주중 이용률이 높은 대여소 (유형 1)의 경우 다른 유형에 비하여 사계절 모두 높은 이용률 을 보였으며, 업무 및 주거 지역에 주로 분포하였다. 주말 이용 률이 높은 대여소(유형 2)의 경우 시기적으로는 봄(4 5월) 과 가을(9 10월)에 집중된 이용 패턴을 보였으며, 공간적으로는 대여소에서 공원 입구까지의 거리가 가까운 것을 확인하였다. 마지막으로 주중과 주말 이용량의 차이가 적은 대여소(유형 3) 는 $1 \cdot 2$ 유형의 특징을 모두 가지고 있는 것을 확인할 수 있었다.

통계적으로는 '대여소에서 공원 출입구'까지의 거리에 대한 유형간 평균의 차이가 유의미한 것으로 나타났다. 이로 인하여 유형 2가 유형 1과 비교하여 공원이 가깝게 위치하기 때문에 PBSS 이용이 많다고 해석할 수 있으나, 인접한 공원의 성격에 따라서도 결과가 다르게 나타날 수 있음을 현장답사에서 발견 할 수 있었다. 유형 1에 해당하는 대여소 중 일부도 여의도 남 쪽에 위치한 샛강생태공원과 가까이 분포하고 있었지만, 유형 2 와 다른 패턴이 나타났다. 이는 생태공원의 특성상 활동적인

Table 6. One-way ANOVA result(PBSS usage)

\begin{tabular}{|c|c|c|c|c|c|c|c|}
\hline & Division & Class & Mean & S.D. & $F$ & $p$ & Bonferroni \\
\hline \multirow{6}{*}{$\begin{array}{c}\text { PBSS } \\
\text { usage } \\
(n)\end{array}$} & \multirow{3}{*}{ Weekday } & 1 & $9,775.6$ & $3,785.5$ & \multirow{3}{*}{.421} & \multirow{3}{*}{.661} & \multirow{3}{*}{ - } \\
\hline & & 2 & $13,365.0$ & $17,734.2$ & & & \\
\hline & & 3 & $10,312.8$ & $7,946.3$ & & & \\
\hline & \multirow{3}{*}{ Weekend } & 1 & $2,405.7$ & $1,206.5$ & \multirow{3}{*}{3.772} & \multirow{3}{*}{$.035^{*}$} & \multirow{3}{*}{$2>1^{*}$} \\
\hline & & 2 & $7,486.2$ & $9,165.9$ & & & \\
\hline & & 3 & $4,296.3$ & $3,432.1$ & & & \\
\hline
\end{tabular}

Table 7. One-way ANOVA result(Distance)

\begin{tabular}{|c|c|c|c|c|c|c|c|}
\hline & Division & Class & Mean & S.D. & $F$ & $p$ & Bonferroni \\
\hline \multirow{6}{*}{$\begin{array}{l}\text { Distance } \\
(\mathrm{m})\end{array}$} & \multirow{3}{*}{$\begin{array}{c}\text { Park } \\
\text { (For park gate) }\end{array}$} & 1 & 375.1 & 175.2 & \multirow{3}{*}{11.153} & \multirow{3}{*}{$.000^{* *}$} & \multirow{3}{*}{$1>2,3^{* *}$} \\
\hline & & 2 & 76.8 & 45.1 & & & \\
\hline & & 3 & 101.3 & 61.9 & & & \\
\hline & \multirow{3}{*}{$\begin{array}{l}\text { Public transportation } \\
\text { (For station) }\end{array}$} & 1 & 336.4 & 248.8 & \multirow{3}{*}{.540} & \multirow{3}{*}{.589} & \multirow{3}{*}{ - } \\
\hline & & 2 & 478.4 & 411.5 & & & \\
\hline & & 3 & 365.8 & 226.3 & & & \\
\hline
\end{tabular}

$$
{ }^{*} p<.05,{ }^{* *} p<.01 \text {. }
$$


프로그램보다는 생태관찰 위주의 프로그램이 운영되고 있으므 로 공원의 성격에 따라서도 PBSS 이용패턴이 달라질 수 있음 을 나타낸다. 따라서 획일적인 PBSS 운영보다는 공간의 다양 한 특성과 수요를 반영한 PBSS의 관리와 프로그램이 운영되 어야 할 필요가 있다.

또한, 개별 대여소 분석에서는 '207(여의나루역 1번출구 앞)' 의 이용 건수가 68,632 건으로 유형 2의 전체 대여량(104,256건) 의 $65.8 \%$ 에 해당하는 것으로 보아 지하철을 이용하여 한강공 원을 이용하는 사람들의 이용행태인 것으로 유추해 볼 수 있다. 향후 서울시 PBSS 정책에서는 특정 대여소에 쏠림현상에 대 응하기 위한 운영관리 프로그램도 고려되어야 할 것이다.

연구를 통해서 공원과 가까이 위치한 PBSS 대여소에서 주 말 이용량이 활발하게 나타나는 것을 확인할 수 있었다. 하지 만, PBSS 대여소가 공원 내에 위치하지 않고, 실제 공원에서의 $\mathrm{PBSS}$ 를 이용하는 이용자의 의견을 고려하지 못한 한계점을 가지고 있다. 추후 연구에서는 공원 내 이용과 관련하여 현장 에 기반한 연구가 추가적으로 이루어져야 할 것이다. 또한, 연 구에서 사용한 자료 외에도 대체 교통수단, 날씨, 인구특성 등 PBSS 이용에 영향을 줄 수 있는 다양한 변수에 대해서 고려되 지 못한 한계를 지닌다.

전국적으로 건강, 탄소저감, 교통 등의 여러 도시문제를 해결 하기 위한 자전거 장려정책이 이루어지고 있다. 서울시는 2019 년에 '자전거 하이웨이(Cycle Rapid Transportation)' 계획을 발표하였으며, 서울식물원, 하늘공원, 여의도공원, 용산가족공 원, 서울숲 등 주요 도시공원을 계획의 거점으로 선정하였다. 이처럼 공원은 자전거를 안전하고 쾌적하게 이용할 수 있는 장 소로서 자전거 이용의 거점 공간으로 활용되고 있음에도 불구 하고, 도시공원에서의 PBSS 이용 증진을 위한 연구가 활발하 게 이루어지지 않고 있다. 앞으로는 다양한 도시민들의 이용수 요를 반영하여 PBSS가 운영될 수 있도록 이용패턴에 대한 지 속적인 연구와 모니터링이 이루어져야 하겠다.

주 1. 서울시설관리공단이 작성한 '공공자전거 종합현황(2019년 7월분)'에 따르면 사무·기술(토목, 전기, 기계, 통신) 32 명, 배송 160 명, 정비 60 명, 안내 31 명이 서울시 공공자전거 프로그램을 위해 근무하고 있다.

주 2. 한국의 PBSS는 법령 『자전거이용 활성화에 관한 법률 제 10 조의 2 , 조례『서울시 자전거이용 활성화에 관한 조례 제 12 조의 2 에 기반하여 만들어졌다. 지방자지단체장이 공공의 자전거 이용 편의를 증진하기 위해서 자전거와 부대시설을 설치할 수 있는 것이 주요 내용이다.

\section{References}

1. Borgnat, P., P. Abry, P. Flandrin, C. Robardet, J. Rouquier and E. Fleury(2011) Shared bicycles in a city: A signal processing and data analysis perspective, Advances in Complex Systems 14(3) : 415-438.

2. Buck, D. and R. Buehler (2012) Bike lanes and other determinants of capital bike share trips. In: Paper Presented at the 91st Annual Meeting of the Transportation Research Board, Washington, Washington DC.
3. Buck, D., R. Buehler, P. Happ, B. Rawls, P. Chung and N. Borecki (2013) Are bikeshare users different from regular cyclists? A first look at short-term users, annual members, and area cyclists in the Washington, D. C., Region. Transportation Research Record Journal of the Transportation Research Board 2387(1): 112-119.

4. Chardon, C. M., G. Caruso and I. Thomas(2016) Bike-share rebalancing strategies, patterns, and purpose. Journal of Transport Geography 55: 22-39.

5. Davis, A. and N. A. Cavill(2007) Cycling and Health; What's the evidence?. Cycling England.

6. Demaio, P.(2009) Bike-sharing: History, impacts, models of provision, and future. Journal of Public Transportation 12(4):41-56.

7. Do, M. S. and Y. S. Noh(2014) Analysis of the affecting factors on the bike-sharing demand focused on Daejeon City. Journal of The Korean Society of Civil Engineers 34(5): 1517-1524.

8. El-Assi, W., M. Salah Mahmoud and K. Nurul Habib(2017) Effects of built environment and weather on bike sharing demand: A station level analysis of commercial bike sharing in Toronto. Transportation 44: 589-613.

9. Faghih-Imani, A. and N. Eluru(2016) Incorporating the impact of spatio-temporal interactions on bicycle sharing system demand: A case study of New York CitiBike system. Journal of Transport Geography 54: 218-227.

10. Fishman, E., S. Washington, N. Haworth and A. Watson(2015) Factors influencing bike share membership: An analysis of Melbourne and Brisbane. Transportation Research Part A: Policy and Practice 71: $17-30$.

11. Froehlich, J., J. Neumann and N. Oliver(2009) Sensing and predicting the pulse of the city through shared bicycling. IJCAI 2009 Proceedings of the 21st International Joint Conference on Artificial Intelligence: 11-17.

12. Guo, Y., J. Zhou, Y. Wu and Z. Li(2017) Identifying the factors affecting bike-sharing usage and degree of satisfaction in Ningbo China. PLoS One 12: e0185100.

13. Heinen, E., K. Maat and B. Wee(2011) The role of attitudes toward characteristics of bicycle commuting on the choice to cycle to work over various distances. Transportation Research Part D: Transport and Environment 16(2): 102-109.

14. Jang, J. M., T. H. Gim and M. Y. Lee(2016) A study on the Seoul public bikes use characteristics: A case of the districts of Yeouido and Sangam. The Seoul Institute 17(4): 77-91.

15. Kaltenbrunner, A., R. Meza, J. Grivolla and J. Codina(2010) Urban cycles and mobility patterns: Exploring and predicting trends in a bicycle-based public transport system. Pervasive and Mobile Computing 6(4) : 455-466.

16. KITA(2018) Recent trends in China's shared bicycle industry and implications(report). Korea International Trade Association: Chengdu Center.

17. KOTI(2018) A Study on Revision of Master Plan for Sustainable National Transportation Logistics. Korea. Ministry of Land, Infrastructure and Transport.

18. Maurer, L. K.(2012) Feasibility study for a bicycle sharing program in Sacramento, California. In: Paper presented at the 91st Annual Meeting of the Transportation Research Board, Washington, D.C.

19. Moon, H. G., D. P. Kim, S. H. Choi and J. O. Kwon(2014) Classification analysis of the physical environment of bicycle road: Focused on Chang Won city, Kyung Nam province, S. Korea. Korean Journal of Environment and Ecology 28(3): 365-373.

20. O'Brien, O., J. Cheshire and M. Batty(2014) Mining bicycle sharing data for generating insights into sustainable transport systems. Journal 
of Transport Geography 34: 262-273.

21. Parkin, J., M. Wardman and M. Page(2008) Estimation of the determinants of bicycle mode share for the journey to work using census data. Transportation 35:93-109.

22. Sa, K. E. and S. G. Lee(2018) Analysis of physical characteristics affecting the usage of public bike in Seoul, Korea: Focused on the different influences of factors by distance to bike station. Journal of Korea Planning Association 53(6): 39-59.

23. Shaheen, S. A., S. Guzman and H. Zhang(2010) Bikesharing in Europe, the Americas, and Asia. 2010 Transportation Research Recode 2143(1):159-167.

24. Wood, J., A. Slingsby and J. Dykes(2011) Visualizing the dynamics of London's bicycle hire scheme. Cartographica 46(4): 239-251.
25. Zhang, Y., T. Thomas, M. Brussel and A. Maarseveen(2016) Expanding bicycle-sharing systems: Lessons learnt from an analysis of usage. PLoS One 11(12): e0168604.

26. Zhou, X.(2015) Understanding spatiotemporal patterns of biking behavior by analyzing massive bike sharing data in Chicago. PLoS One 10(10): e0137922.

27. City Lab, https://www.citylab.com/city-makers-connections/ bikeshare/ accessed 2020.1.9.

28. Korea National Spatial Data Infrastructure Portal Open API, http:// openapi.nsdi.go.kr/ accessed 2020.1.9

29. Metro Bike, http://www.metrobike.net/ accessed 2019.8.7.

30. Seoul Open Data Plaza, http://data.seoul.go.kr/ accessed 2019.11.24.

Received : 10 December, 2019

Revised : 02 January, 2020

28 January, 2020

(1st)

14 February, 2020

(2nd)

Accepted : 14 February, 2020

3인익명 심사필 